\title{
A Processable Mullite Precursor Prepared by Reacting Silica and Aluminum Hydroxide with Triethanolamine in Ethylene Glycol: Structural Evolution on Pyrolysis
}

\author{
Pallavi Kansal and Richard M. Laine ${ }^{\star}$ \\ Departments of Materials Science and Engineering, Chemistry, and the Macromolecular Science and \\ Engineering Program, University of Michigan, Ann Arbor, Michigan 48109-2136
}

Florence Babonneau

Chimie de la Condensée, Université Pierre et Marie Curie/CNRS, 75005 Paris, France

\begin{abstract}
A simple, processable precursor to mullite can be synthesized in quantities of $100 \mathrm{~g}$ in a few hours by direct reaction of silica, aluminum hydroxide, and triethanolamine in ethylene glycol. To delineate a processing window whereby precursor shapes can be transformed into mullite, the chemical and phase microstructural evolution of this precursor on pyrolysis to selected temperatures in air is followed by thermal gravimetric analysis, differential thermal analysis, diffuse reflectance infrared Fourier transform spectroscopy, solid-state ${ }^{27} \mathrm{Al}$ and ${ }^{29} \mathrm{Si}$ nuclear magnetic resonance, X-ray diffractometry, and Brunauer-EmmettTeller analytical methods. The precursor behaves as a single-phase, atomically mixed material that initially transforms to a porous, amorphous aluminosilicate when heated to temperatures as high as $950^{\circ} \mathrm{C}$. Above $950^{\circ} \mathrm{C}$, the precursor first transforms to tetragonal mullite, based on comparison with the literature, and, on continued heating above $1200^{\circ} \mathrm{C}$, to orthorhombic mullite with coincident loss of porosity.
\end{abstract}

\section{Introduction}

$\mathrm{M}$ ULLITE $\left(3 \mathrm{Al}_{2} \mathrm{O}_{3} \cdot 2 \mathrm{SiO}_{2}\right)$ is an important and widely studied ceramic material. It is used in a diverse number of applications, including microelectronic packaging, high-temperature protective coatings, microwave dielectrics, and infraredtransmitting materials. ${ }^{1-10}$ Mullite substrates are expected to be used increasingly instead of alumina $\left(\mathrm{Al}_{2} \mathrm{O}_{3}\right)$ substrates, which are currently used in high-performance midrange computers, because of a lower thermal-expansion mismatch in the mullitealumina-silicon system compared to alumina. ${ }^{3,11}$ In addition, mullite is considered to be a candidate material for hightemperature structural applications, because of its low coefficient of thermal expansion $\left(5 \times 10^{-6} /{ }^{\circ} \mathrm{C}\right)$, good thermal-shock fracture resistance, low true density, high creep resistance, good chemical and thermal stability, high melting point $\left(1828^{\circ} \pm 10^{\circ} \mathrm{C}\right)$, and excellent toughness and strength. ${ }^{9-18}$ Thus, mullite is an excellent target ceramic material to dem-

\footnotetext{
J. W. Halloran—contributing editor
}

\footnotetext{
Manuscript No. 191634. Received August 1, 1996; approved March 10, 1997. Supported by the U.S. Office of Naval Research through Grant No. N00014-92J-1711, the Army Research Laboratories through Contract No. DOD-C-DAAL04-91C-0068, and the Air Force Office of Scientific Research through Contract No FQ8671-9600549. Travel for authors FB and RML was supported by NSF/CNRS under Travel Grant No. INT-9216604.

"Member, American Ceramic Society.
}

onstrate the utility of our recently discovered synthetic route to aluminosilicate precursors directly from silica $\left(\mathrm{SiO}_{2}\right)$ and aluminum hydroxide $\left(\mathrm{Al}(\mathrm{OH})_{3}\right)$ (vide infra) ${ }^{19-22}$

Mullite can be synthesized by either traditional powder or chemical processing methods. In the traditional approach, mullite is formed from naturally occurring aluminosilicate minerals, e.g., sillimanite. ${ }^{9}$ In minerals processing, relatively coarse (micrometer-range) powders are used; thus, high temperatures $\left(>1700^{\circ} \mathrm{C}\right)$ are required to complete the solid-state reactions. Despite the high temperatures, segregated $\mathrm{Al}_{2} \mathrm{O}_{3^{-}}$and $\mathrm{SiO}_{2}-$ rich regions often remain. Mineral sources often contain high impurity levels (iron oxide, titanium oxide, etc.) that are unacceptable in advanced ceramic applications. Contamination problems can be avoided by sintering mixtures of high-purity oxides or hydroxides of aluminum and silicon. Unfortunately, high sintering temperatures $\left(>1650^{\circ} \mathrm{C}\right)$ are still required and mixing is still at the micrometer level. ${ }^{1,9}$ Thus, homogeneous microstructures remain difficult to obtain.

In contrast, in chemical processing, the intimacy of mixing dictates the mullitization temperature and phase purity in the final product. ${ }^{23-28}$ If the homogeneity is at the atomic level ("single phase"), as in chemical vapor deposition (CVD), spray pyrolysis, and polymer precursor methods, direct mullitization can be observed, as evidenced by an exothermic reaction at $\sim 980^{\circ} \mathrm{C}$. In contrast, if the homogeneity is in the nanometer-to-micrometer range ("colloidal" or "diphasic"), mullitization occurs through a transient $\mathrm{Al}_{2} \mathrm{O}_{3}$ phase and is often evidenced by a second exotherm at a temperature $>1200^{\circ} \mathrm{C}^{24,28}$ For example, powders or gels that are formed by the fast hydrolysis of various alkoxides or salts are generally diphasic. ${ }^{4,10,23,24}$ Despite the lower processing temperatures (compared to traditional approaches), segregation during microstructural development is often observed.

The exact mechanism(s) of microstructural evolution (nucleation and growth) in the formation of mullite remain(s) a subject of much debate. In the traditional approach, mullite forms via an interfacial reaction between $\mathrm{Al}_{2} \mathrm{O}_{3}$ and $\mathrm{SiO}_{2}{ }^{1,9}$ Growth seems to occur by diffusion of aluminum and silicon through the mullite layer. In nanoscale diphasic systems, mullite nucleation is suggested to occur within the siliceous amorphous matrix rather than at the interface. ${ }^{8,9}$ Alternately, mullite nucleation is reported to occur via an aluminum-silicon spinel phase, which is responsible for the exotherm that is observed at temperatures $>1200^{\circ} \mathrm{C}$. Mullite formation by direct solid-state reaction between $\mathrm{Al}_{2} \mathrm{O}_{3}$ and amorphous $\mathrm{SiO}_{2}$ also is proposed to occur. ${ }^{9}$

Despite the controversy about the mechanism(s) of nucleation and microstructural development, there continues to be a need for low-cost, high-purity processable precursors for forming mullite shapes. As briefly noted above, we recently described a low-cost route to easily processed aluminosilicate 
precursors by reaction of $\mathrm{SiO}_{2}, \mathrm{Al}(\mathrm{OH})_{3}$, and Group I/II metal hydroxides/oxides in ethylene glycol (EG) and triethanolamine (TEA) using the "oxide one-pot synthesis" (OOPS) process. $^{9-22}$ The purpose of the current work is to provide details about the chemical and microstructural evolution that occurs during the pyrolytic transformation of the OOPS mullite precursor to amorphous and then ceramic (mullite) materials and to delineate an appropriate processing window. The processing protocols that are developed in the following study will help to identify pyrolysis processing parameters for ceramic shapes such as coatings, fibers, and thin films. We will report on the use of this precursor to process mullite/carbon coatings on graphite fibers in the near future. ${ }^{21}$

\section{Experimental Procedure}

\section{(1) General Procedures}

All chemicals were purchased from standard vendors and used as-received, except for EG, which was distilled under nitrogen gas before use. EG that was recovered from the reaction also was redistilled and recycled. Care was taken not to expose the reaction contents to the atmosphere, because of their slight moisture sensitivity.

(A) Synthesis of Mullite $\left(3 \mathrm{Al}_{2} \mathrm{O}_{3} \cdot 2 \mathrm{SiO}_{2}\right)$ Precursor: The mullite precursor was synthesized directly from aluminum hydroxide hydrate $\left(\mathrm{Al}(\mathrm{OH})_{3} \cdot x \mathrm{H}_{2} \mathrm{O}\right)\left(53.5 \mathrm{wt} \% \mathrm{Al}_{2} \mathrm{O}_{3}\right.$, Aldrich Chemical Co., Milwaukee, WI), $\mathrm{SiO}_{2}$ (99.99 wt\%, Cabot Corp., Tuscola, IL), analytical-grade EG (Mallinckrodt, Paris, $\mathrm{KY}$ ), and TEA (Aldrich). $\mathrm{Al}(\mathrm{OH})_{3} \cdot x \mathrm{H}_{2} \mathrm{O}\left(55.0 \mathrm{wt} \% \mathrm{Al}_{2} \mathrm{O}_{3}\right.$ ) (338 mmol, $31.4 \mathrm{~g}$ ), TEA (338 mmol, $50.4 \mathrm{~g}$ ), and excess EG $(300-350 \mathrm{~mL})$ were placed in a schlenk flask (capacity of 500 $\mathrm{mL}$ ). The mixture was heated to the EG distillation temperature $\left(200^{\circ} \mathrm{C}\right)$, under nitrogen gas, with constant mechanical stirring. The $\mathrm{Al}(\mathrm{OH})_{3} \cdot x \mathrm{H}_{2} \mathrm{O}$ dissolved readily with continuous, slow distillative removal of both $\mathrm{EG}$ and byproduct $\mathrm{H}_{2} \mathrm{O}$. The reaction became clear in 1-2 h, after $250-300 \mathrm{~mL}$ of EG and water distilled off, and a clear yellow solution was obtained. The reaction was allowed to cool to room temperature.

$\mathrm{SiO}_{2}$ (113 mmol, $6.8 \mathrm{~g}$ ), TEA (113 mmol, $16.8 \mathrm{~g}$ ), and excess EG $(200 \mathrm{~mL})$ were added to the above-mentioned reaction. The mixture was heated again under nitrogen gas with constant mechanical stirring. As distillation continued, $\mathrm{SiO}_{2}$ dissolved and, in 1-2 $\mathrm{h}$, the reaction became clear. The reaction was stopped after 200-250 mL of EG and byproduct water had distilled off, which gave a clear, yellow viscous solution. The solvent was removed by vacuum evaporation, and the resulting residue was vacuum dried $\left(10^{-2}\right.$ torr $\left.(\sim 1.3 \mathrm{~Pa})\right)$ at $\sim 210^{\circ} \mathrm{C}$ for $2-3 \mathrm{~h}$ to remove residual EG and TEA, if any. On cooling, a hard, brittle polymer was obtained that was freeze fractured (alternate cooling in liquid nitrogen and warming in hot water), transferred to a container, and stored in the inert atmosphere of a glove box (Model MO40-2-Dri-Lab, Vacuum Atmospheres, Co., Hawthorne, CA). The yield of the reaction was $\sim 100 \mathrm{~g}$ (ceramic yield was $\sim 23 \mathrm{wt} \%$ ).

(B) Pyrolyses: All pyrolyses were performed in a singlezone tube furnace (Model 58114, Lindberg, Watertown, WI) (heating zone was $\sim 7-8 \mathrm{~cm}$ long) that was equipped with a programmable temperature controller (Model 818P, Eurotherm, Northing, U.K.). Samples (1-2 g) were placed in an $\mathrm{Al}_{2} \mathrm{O}_{3}$ boat $(3 \mathrm{~cm} \times 6 \mathrm{~cm})$ and then inside a quartz tube. The quartz tube was sealed with a ported cap, inserted into the furnace, and connected to a supply of synthetic air. The samples were heated at $10^{\circ} \mathrm{C} / \mathrm{min}$ in air to selected temperatures, followed by a hold of $1 \mathrm{~h}$, and then furnace cooled. The samples were taken out of the quartz tube and stored in air for further characterization.

\section{(2) Materials Characterization}

The phase transformations and chemical changes that occur during pyrolysis of the mullite precursor were characterized. The characterization methods included thermal gravimetric analysis (TGA) and differential thermal analysis (DTA), powder X-ray diffractometry (XRD), solid-state magic-angle spinning ${ }^{29} \mathrm{Si}$ and ${ }^{27} \mathrm{Al}$ nuclear magnetic resonance $\left({ }^{29} \mathrm{Si}\right.$ and ${ }^{27} \mathrm{Al}$ MAS NMR), diffuse reflectance infrared Fourier transform (DRIFT) spectroscopy, scanning electron microscopy (SEM), and surface area and porosimetry, as described below.

(A) Thermal Analyses: Thermal analyses were performed (Model Thermal Analyst 2200 with a Hi-Res TGA 2950 Thermogravimetric Analyzer and a DSC 2910 Differential Scanning Calorimeter equipped with a 1600 DTA Differential Thermal Analyzer module; TA Instruments, New Castle, DE). TGA samples that averaged $15-20 \mathrm{mg}$ were loaded in a platinum pan and heated in flowing $\left(60 \mathrm{~cm}^{3} / \mathrm{min}\right)$ synthetic air to $1000^{\circ} \mathrm{C}$, in "Hi-Res 4.0 mode," at $50^{\circ} \mathrm{C} / \mathrm{min}$. Hi-Res mode decreases the heating rate as the rate of mass loss increases, which provides sharply defined thermal events (decomposition, oxidation, etc.). DTA measurements (sample sizes of $\sim 30 \mathrm{mg}$ ) were performed using platinum crucibles, under a continuous flow (50 $\mathrm{cm}^{3} / \mathrm{min}$ ) of synthetic air, at $10^{\circ} \mathrm{C} / \mathrm{min}$ to $1400^{\circ} \mathrm{C}$. Calcined $\mathrm{Al}_{2} \mathrm{O}_{3}$ (Alcoa, Pittsburgh, PA) was used as a reference.

(B) XRD: XRD powder patterns were determined using a rotating anode goniometer (Rigaku Denki Co., Tokyo, Japan). Powder samples (100-200 mg) were ground with an $\mathrm{Al}_{2} \mathrm{O}_{3}$ mortar and pestle, packed in a glass specimen holder, and placed in the goniometer. Scans were continuous from $5^{\circ}-80^{\circ}$ $2 \theta$ at a scan rate of $10^{\circ} 2 \theta / \mathrm{min}$ using $0.05^{\circ} 2 \theta$ increments and $\mathrm{Cu} K \alpha(\lambda=1.542 \AA)$ radiation. Scans that were used for comparing the integrated peak intensities for the (120) and (210) peaks were taken at $1^{\circ} 2 \theta / \mathrm{min}$, using $0.05^{\circ} 2 \theta$ increments. The peak positions and the relative intensities of the powder patterns were identified by comparison with ICDD ${ }^{\dagger}$ File Card No. 15-776 to identify the crystalline phases.

(C) Solid-State MAS NMR: ${ }^{29} \mathrm{Si}$ and ${ }^{27} \mathrm{Al}$ solid-state MAS NMR spectra were obtained for pyrolyzed samples to study changes in chemical structure during pyrolytic transformation. ${ }^{*}$ The ${ }^{29} \mathrm{Si}$ MAS NMR spectra were recorded on either of two spectrometers (Models MSL $300(59.6 \mathrm{MHz})$ or MSL400 (79.5 $\mathrm{MHz}$ ), Bruker) using $7 \mathrm{~mm}$ MAS probes (Bruker, Wissembourg, France). The spinning rate was $5 \mathrm{kHz}$. The repetition time was $60 \mathrm{~s}$ with a pulse width of $2 \mu \mathrm{s}$ ( $30^{\circ}$ pulse angle). The ${ }^{27} \mathrm{Al}$ MAS NMR spectra were recorded on the MSL300 spectrometer (78.2 MHz) with a $4 \mathrm{~mm}$ MAS probe (Bruker). The spinning rate was $15 \mathrm{kHz}$. A pulse width of $1 \mu$ s was used, with repetition times of $1 \mathrm{~s}$. The ${ }^{29} \mathrm{Si}$ MAS NMR spectra were simulated using the WIN-FIT software program.

(D) DRIFT Spectroscopy: DRIFT spectra were recorded on a Galaxy Series FTIR 3000 spectrometer (Mattson Instruments, Madison, WI). Optical-grade random cuttings of potassium bromide $(\mathrm{KBr})$ (International Crystal Laboratories, Garfield, NJ) were ground using an $\mathrm{Al}_{2} \mathrm{O}_{3}$ mortar and pestle. DRIFT spectroscopy samples were prepared by mixing $0.3-1.0$ wt $\%$ of the sample to be analyzed with $\mathrm{KBr}$.

Sample concentrations were maintained at $<1 \mathrm{wt} \%$ to ensure adherence to Beer's law. The dilute samples that were prepared in $\mathrm{KBr}$ were subsequently packed firmly in the sample holder, leveled off at the upper edge to provide a smooth surface, and transferred to the Fourier transform infrared spectroscopy (FTIR) sample chamber, which was constantly flushed with nitrogen gas. A minimum of 64 scans were collected for each sample, at a resolution of $\pm 4 \mathrm{~cm}^{-1}$. Peak positions were identified using a standard peak-searching program.

(E) Surface Area and Porosimetry: Surface area and micropore analyses were conducted at a temperature of $77 \mathrm{~K}$ using porosimetry equipment (Model ASAP2000, Micromeritics Instruments Group, Norcross, GA) with nitrogen as the

${ }^{\dagger}$ International Centre for Diffraction Data, Newtowne Square, PA (formerly Joint Committee on Powder Diffraction Standards (JCPDS), Swarthmore, PA).

The solid-state NMR experiments were performed by Florence Babonneau and Jocelyne Maquet, Laboratoire Chimie de la Matière Condensée, Université de Pierre et Marie Curie, Paris, France. 
adsorbate gas. Prior to analysis, samples were degassed at $400^{\circ} \mathrm{C}$ under high vacuum for $12 \mathrm{~h}$. Surface areas were calculated using the five-point method. Micropore analysis was performed using differential function theory (DFT) with slitlike pores in carbon as the model; thus, pore size is reported as a pore width.

(F) SEM: The bulk material microstructure was examined by using an SEM microscope (Model S800, Hitachi, Tokyo, Japan) that was operating at $5 \mathrm{keV}$. SEM samples were prepared by mounting pyrolyzed powder samples on an aluminum stub using a double-stick tape. Powder samples were sputter coated with a layer of $\mathrm{Au}-\mathrm{Pd}$ for $\sim 45 \mathrm{~s}$ at $10 \mathrm{mV}$, to enhance their conductivity.

\section{Results and Discussion}

The mullite precursor can be synthesized directly by reacting stoichiometrically correct mixtures of $\mathrm{SiO}_{2}$ and $\mathrm{Al}(\mathrm{OH})_{3}$ in $\mathrm{EG}$ with TEA. ${ }^{19,21}$ Alternately, the precursor can be prepared by reacting the individual components (TEA-Al and TEA-Si-EG, which are synthesized via reactions (1) and (2).
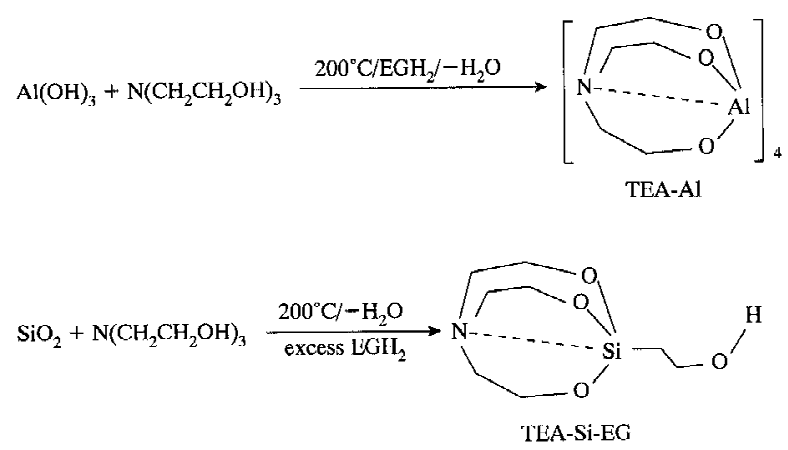

TEA-A1 and TEA-Si-EG both have been characterized in detail. ${ }^{19,22}$ Mixtures of TEA-Al and TEA-Si-EG, in a 3:1 ratio, that are heated briefly in EG, followed by vacuum drying, provide the mullite precursor. One-hundred-gram quantities can be prepared in 2-3 h using either method. The theoretical ceramic yield is $28.2 \%$, based on this $3: 1$ mixture.

Following synthesis, precursor samples were first analyzed by TGA and DTA to delineate the decomposition patterns, which, in turn, were used to define an approximate processing window for complete pyrolytic transformation of the precursor to ceramic material. Samples that were heated to selected temperatures were characterized by XRD, DRIFT spectroscopy, ${ }^{29} \mathrm{Si}$ and ${ }^{27} \mathrm{Al}$ MAS NMR, and SEM. The XRD data permit identification of crystalline phases and microstructural development that occur at selected temperatures. MAS NMR provides complementary information on the evolution of the local environments of silicon and aluminum sites in the pyrolyzed samples. DRIFT spectroscopy can be used to derive information about the phase or atomic transformations, crystallinity, impurities, and surface characteristics such as the presence of adsorbed $\mathrm{H}_{2} \mathrm{O}$, etc. Complete characterization of the precursor as it is pyrolyzed in air to selected temperatures is presented below.

\section{(1) Thermal Analyses}

The TGA (Fig. 1) of the mullite precursor shows a $1000^{\circ} \mathrm{C}$ ceramic yield of $23.0 \%$, which is $\sim 5 \%$ below theory $(28.2 \%)$. The lower experimental ceramic yield is likely caused by some retained, unreacted TEA and free EG in the sample. Even though the sample has been vacuum dried $\left(210^{\circ} \mathrm{C}\right.$ for $\left.2-3 \mathrm{~h}\right)$, the highly viscous precursor resists solvent removal as it hardens to a hard plastic on drying. Some support for solvent retention is found in the TGA, which shows three major losses.

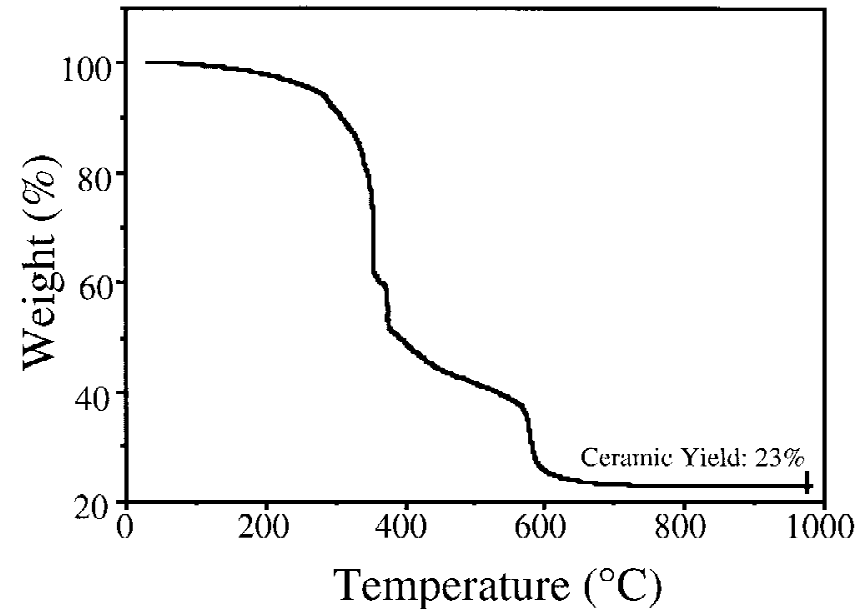

(A)

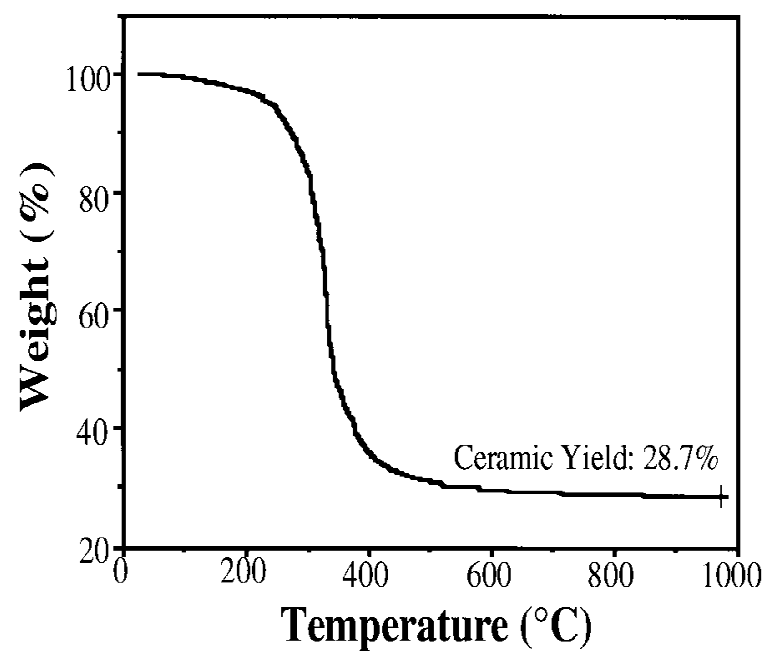

(B)

Fig. 1. TGA of mullite precursor heated in "Hi-Res 4.0 mode" at $50^{\circ} \mathrm{C} / \mathrm{min}(\mathrm{A})$ in air and (B) in nitrogen to $1000^{\circ} \mathrm{C}$.

The first mass loss $(\sim 6 \%)$ in the temperature range of $80^{\circ}-$ $260^{\circ} \mathrm{C}$ likely results from volatilization of unreacted TEA and free EG. The second mass loss $(\sim 42 \%)$ occurs in the temperature range of $270^{\circ}-370^{\circ} \mathrm{C}$ and is due to the decomposition of organic ligands (TEA and EG). If samples of the precursor are heated in nitrogen (Fig. 1(B)), the second mass loss is greater and the third mass loss $(\sim 30 \%)$ is not observed. ${ }^{21}$ Thus, we attribute the mass loss at $375^{\circ}-610^{\circ} \mathrm{C}$ to oxidation of char that is formed by oxidative crosslinking of the organic ligands, which cannot occur in nitrogen.

As the organic ligands decompose, a number of reactions probably occur simultaneously. The specific decomposition reactions have not, as yet, been delineated. ${ }^{20}$ The precursor consists primarily of ethyleneoxy ligands $\left(\mathrm{Si}-\mathrm{OCH}_{2} \mathrm{CH}_{2} \mathrm{O}-\right.$ and $\mathrm{M}-\mathrm{OCH}_{2} \mathrm{CH}_{2}-\mathrm{N}=$ ) that can thermally fragment to form volatile compounds $\left(\mathrm{CH}_{2}=\mathrm{CH}_{2}, \mathrm{CH}_{2} \mathrm{O}, \mathrm{CH} \equiv \mathrm{CH}, \mathrm{CH}_{4}\right.$, etc. $)$ and hydroxylated species (e.g., $\mathrm{Si}(\mathrm{O})_{x}(\mathrm{OH})_{y}$ and $\left.\mathrm{Al}(\mathrm{O})_{m}(\mathrm{OH})_{n}\right){ }^{20}$

When samples are heated in air, the decomposition process seems to be complicated by oxidative crosslinking. ${ }^{20}$ In oxidative crosslinking, carbon radicals are generated and subsequently couple to form extended polymeric materials (char). On continued heating, the char can undergo oxidative chain fragmentation, which leads to more volatiles or more crosslinked char. The retained $\mathrm{C}-\mathrm{H}$ bonds in the char generate $\mathrm{H}_{2} \mathrm{O}$ (and $\mathrm{CO}$ or $\mathrm{CO}_{2}$ ) on oxidation, which generates fresh 
$\mathrm{M}-\mathrm{OH}$ groups. Because the char becomes more highly crosslinked with time and at higher temperature, it is hard to oxidize; hence, an extended temperature range $\left(375^{\circ}-610^{\circ} \mathrm{C}\right)$ is required for its removal.

The DTA (Fig. 2) shows a sharp exotherm at $380^{\circ} \mathrm{C}$ at the end of the major mass loss event $\left(200^{\circ}-360^{\circ} \mathrm{C}\right)$ that is observed in the TGA. The TGA shows that, by $370^{\circ} \mathrm{C}, \sim 50 \%$ of the mass is lost; thus, it is unlikely that this exotherm results from organic ligand decomposition. One possible explanation is that as the organic ligands decompose to volatiles, inorganic speciese.g., $\mathrm{Si}(\mathrm{O})_{x}(\mathrm{OH})_{y}$ and $\mathrm{Al}(\mathrm{O})_{m}(\mathrm{OH})_{n}$-form concurrently (see "DRIFT Spectroscopy,' Section III (5)). These species must react at some point to form the $\mathrm{Si}-\mathrm{O}-\mathrm{Al}$ network (by loss of $\mathrm{H}_{2} \mathrm{O}$ ). We suggest that network formation is most likely responsible for the observed exotherm at $380^{\circ} \mathrm{C} .{ }^{20}$ The ${ }^{29} \mathrm{Si} \mathrm{NMR}$ analysis (vide infra) indicates the presence of $\sim 80 \% \mathrm{Si}-\mathrm{O}-\mathrm{Al}$ sites at the lowest temperature $\left(400^{\circ} \mathrm{C}\right)$ that is examined. Thus, an $\mathrm{Si}-\mathrm{O}-\mathrm{Al}$ network does form at these temperatures, which provides some support for this interpretation of the exotherm at $380^{\circ} \mathrm{C}$. The exotherm at $610^{\circ} \mathrm{C}$ coincides with the third mass loss and likely corresponds to char oxidation. This exotherm is not observed when the precursor is pyrolyzed in nitrogen. ${ }^{21}$

The sharp exotherm that is observed at $990^{\circ} \mathrm{C}$ is typical of crystallization to mullite and/or a $\gamma-\mathrm{Al}_{2} \mathrm{O}_{3}$-type spinel phase. ${ }^{1,4,5,9,10,14,15,17,23-28}$ No other exotherm is observed at higher temperatures $\left(>1200^{\circ} \mathrm{C}\right)$, as expected for single-phase precursors that are reported to exhibit only one exotherm at temperatures of $980^{\circ}-990^{\circ} \mathrm{C}$, because of spinel or mullite (or tetragonal mullite) phase formation. ${ }^{9,23-25}$ A more detailed discussion of the meaning of this exotherm is presented below.

\section{(2) $X R D$}

The powder patterns for mullite samples that have been pyrolyzed in air to selected temperatures are shown in Fig. 3. The samples at temperatures $<1000^{\circ} \mathrm{C}$ are $\mathrm{X}$-ray amorphous, as indicated by the broad maxima. The $1000^{\circ} \mathrm{C}$ XRD pattern indicates crystallization, as evidenced by sharp peaks at $2 \theta$ values of $\sim 16^{\circ}, 26^{\circ}, 35^{\circ}, 41^{\circ}$, etc. These peaks correspond to ICDD File Card No. 15-776 for stoichiometric mullite, $3 \mathrm{Al}_{2} \mathrm{O}_{3}$. $2 \mathrm{SiO}_{2} \cdot{ }^{4}$ These data appear to be in contrast with the $1000^{\circ} \mathrm{C}$ ${ }^{29} \mathrm{Si}$ NMR spectrum (vide infra), which suggests phase separation, although it correlates with the DTA exotherm at $990^{\circ} \mathrm{C}$, commonly thought to result because of mullitization. Also, there is no evidence of the spinel phase that was observed by Gerardin et al. ${ }^{24}$ and Chakravorty ${ }^{28}$ in single-phase precursors synthesized by the sol-gel method. This suggests that the OOPS-precursor-derived material has a higher degree of homogeneity because of better atomic mixing. At $1200^{\circ}$ and $1300^{\circ} \mathrm{C}$, the peaks sharpen (peak width decreases and intensity increases) because of grain growth. Thomson et al. ${ }^{25}$ used the splitting of the peak at $26.15^{\circ} 2 \theta$ in tetragonal mullite (on heating at temperatures $>1000^{\circ} \mathrm{C}$ ) as a means of estimating the extent of conversion of the tetragonal phase to the orthorhombic phase. Thus, the ratio of the integrated peak intensities for the (120) and (210) peaks (at $25.97^{\circ}$ and $26.26^{\circ} 2 \theta$, respectively) for ICDD File Card No. 15-776 (mullite crystallized at $1700^{\circ} \mathrm{C}$ ) is used as the reference. On this basis, the samples that are produced at selected temperatures are as follows: only tetragonal at $1000^{\circ} \mathrm{C}$ (no splitting), $80 \%$ orthorhombic at $1200^{\circ} \mathrm{C}$, and $87 \%$ orthorhombic at $1400^{\circ} \mathrm{C}$. These results are qualitatively in agreement with the ${ }^{29} \mathrm{Si} \mathrm{NMR}$ results that are presented below.

\section{(3) ${ }^{29} \mathrm{Si}$ MAS NMR}

Figure 4 displays ${ }^{29} \mathrm{Si}$ MAS NMR spectra for samples that have been pyrolyzed to selected temperatures. The $400^{\circ} \mathrm{C}$ sample spectrum is characterized by a primary, broad signal with a maximum at $-85 \mathrm{ppm}(\sim 80 \%$ of the total silicon sites by integration), and a smaller component at $-106 \mathrm{ppm}(\sim 20 \%)$. The $-85 \mathrm{ppm}$ chemical shift is typical for $\mathrm{Si}(\mathrm{OAl})_{4}$ units $^{24,27,29-32}$ and shows that these units dominate early evolutionary stages. However, the asymmetry of the peak strongly suggests that mixed units $\left(\mathrm{Si}(\mathrm{OAl})_{4-x}(\mathrm{OSi})_{x}(x \neq 0)\right.$ also are present, and, indeed, the $-106 \mathrm{ppm}$ signal results from $\mathrm{Si}(\mathrm{OSi})_{4}$ sites. The spectra do not change much up to $950^{\circ} \mathrm{C}$, although a shift in the main peak position (Fig. 5) toward -90 ppm suggests an enrichment of the aluminosilicate phase in $\mathrm{SiO}_{2}$, which is coincident with the broadening of the signals at $950^{\circ} \mathrm{C}$.

The main change occurs at $1000^{\circ} \mathrm{C}$ : the spectrum clearly shows two broad signals, centered at $-88 \mathrm{ppm}(\sim 53 \%)$ and $-108 \mathrm{ppm}(\sim 47 \%)$, which strongly suggests the presence of an $\mathrm{Al}_{2} \mathrm{O}_{3}$-rich, aluminosilicate phase and $\mathrm{SiO}_{2}$-rich region. The amount of $\mathrm{SiO}_{2}$-rich sites increases drastically in the temperature range of $950^{\circ}-1000^{\circ} \mathrm{C}$, from $20 \%$ to $50 \%$ (Fig. 6), in the temperature range that corresponds to the onset of crystallization (by DTA and XRD). However, despite the crystallization of mullitelike peaks in the XRD pattern, the ${ }^{29} \mathrm{Si}$ NMR signals are broad, even the $-88 \mathrm{ppm}$ peak, which is typical of silicon sites in mullite. This suggests that a large distribution of sites (some disorder) exists in the material. Note that XRD detects only the long-range order in a sample, whereas NMR detects the local environment around the silicon atom. Similar results were reported by Gerardin et al., ${ }^{24}$ as discussed below.

In contrast to the $1000^{\circ} \mathrm{C}$ samples, the $1300^{\circ} \mathrm{C}$ sample shows a ${ }^{29} \mathrm{Si}$ MAS NMR spectrum that is typical of crystalline mullite, with three sharp peaks at $-87.2,-90.5$ and $-94.7 \mathrm{ppm}$ and

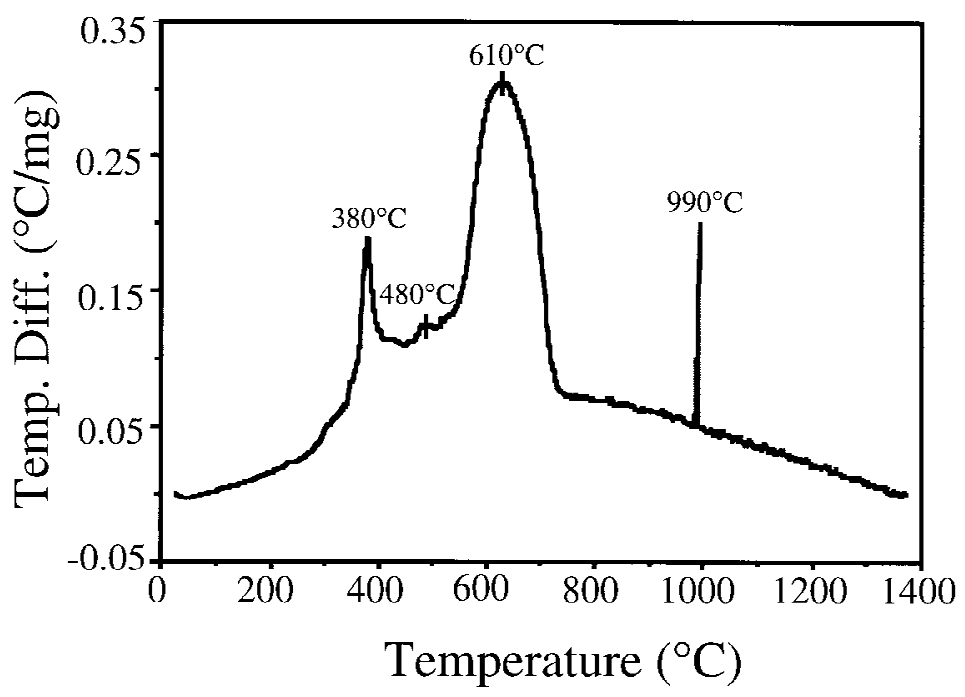

Fig. 2. DTA of mullite precursor heated at $10^{\circ} \mathrm{C} / \mathrm{min}$ in air to $1400^{\circ} \mathrm{C}$. 


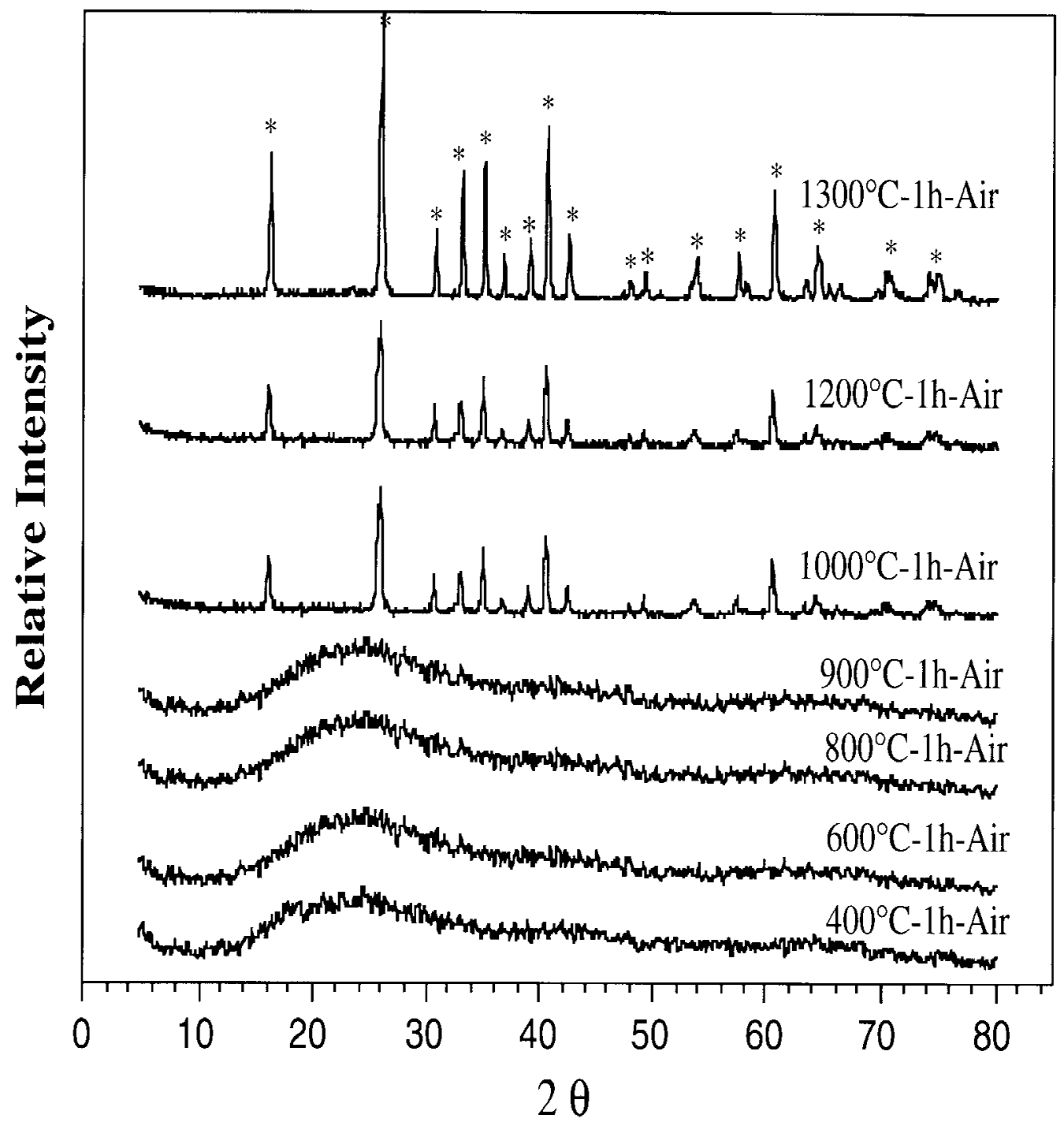

Fig. 3. XRD patterns of mullite precursor pyrolyzed to selected temperatures ((*) $3 \mathrm{Al}_{2} \mathrm{O}_{3} \cdot 2 \mathrm{SiO}_{2}, \mathrm{ICDD}$ File Card No. 15-776).

a shoulder at $-81 \mathrm{ppm}$, in good agreement with previous NMR studies of mullite. ${ }^{24,27,29-32} \mathrm{~A}$ signal at approximately -108 $\mathrm{ppm}$ is still present, albeit with a much-lower intensity $(\sim 18 \%$, Fig. 6), which shows that the $\mathrm{SiO}_{2}$-rich and $\mathrm{Al}_{2} \mathrm{O}_{3}$-rich sites that are formed at $1000^{\circ} \mathrm{C}$ recombine to approach a stoichiometric mullite. As the precursor is heated to $1400^{\circ} \mathrm{C}$, the peaks become more defined, because of further crystallization, and no $\mathrm{SiO}_{2}$ sites are detected.

Gerardin et al. ${ }^{24}$ and Jaymes et al. ${ }^{27}$ reported the formation of $\mathrm{Al}_{2} \mathrm{O}_{3}$ - and $\mathrm{SiO}_{2}$-rich regions (by ${ }^{29} \mathrm{Si} \mathrm{NMR}$ ) for pyrolyzed single-phase precursors that exhibit single exotherms at $\sim 980^{\circ} \mathrm{C}$ and mullite diffraction patterns in the XRD (at $1000^{\circ} \mathrm{C}$ ). Samples in the work of Gerardin et al..$^{24}$ were first heated at a rate of $1^{\circ} \mathrm{C} / \mathrm{min}$ to $800^{\circ} \mathrm{C}$ and then heated at a rate of $3^{\circ} \mathrm{C} / \mathrm{min}$ to selected temperatures $\left(950^{\circ}\right.$ and $\left.1000^{\circ} \mathrm{C}\right)$, followed by holds of $6 \mathrm{~h}$, and further annealed for $24 \mathrm{~h}$. The $950^{\circ}$ and $1000^{\circ} \mathrm{C}$ spectra show two main features: a broad peak, centered at $-110 \mathrm{ppm}$, which is attributed to $\mathrm{SiO}_{2}$-rich sites, and a narrow peak at $-86 \mathrm{ppm}$, with shoulders at -90 and -93 $\mathrm{ppm}$, which corresponds to mullite. Integration indicates that $35 \%$ of the $\mathrm{SiO}_{2}$ sites are $\mathrm{Si}(\mathrm{OSi})_{4}$, as opposed to $47 \%$ in the OOPS-derived mullite sample. Although the Jaymes et al. ${ }^{27}$ work also shows the same segregation at $1000^{\circ} \mathrm{C}$, no integration was reported.

Gerardin et al. ${ }^{24}$ observed shoulders ( -90 and $-93 \mathrm{ppm}$ ) for mullite at $1000^{\circ} \mathrm{C}$ that were not observed in our samples or by Jaymes et al. ${ }^{27}$ This difference in the $\mathrm{SiO}_{2}$-rich sites (35\% vs.
47\%) and the absence of shoulders (due to mullite) in the OOPS-derived mullite precursor sample that was heated to $1000^{\circ} \mathrm{C}$ may be due to different heating schedules. OOPSderived mullite samples were heated at $10^{\circ} \mathrm{C} / \mathrm{min}$ to selected temperatures (e.g., $1000^{\circ} \mathrm{C}$ ), followed by a hold of only $1 \mathrm{~h} \cdot{ }^{20}$ The slower heating rates and longer holds $(6 \mathrm{~h})$ for the Gerardin et al. $^{24}$ samples allow diffusion and may result in a morehomogeneous and better-crystallized material, in comparison to the OOPS-derived $1000^{\circ} \mathrm{C}$ mullite sample.

\section{(4) ${ }^{27}$ Al MAS NMR}

The ${ }^{27} \mathrm{Al}$ MAS NMR spectra (Fig. 7) were recorded on pyrolyzed samples, with special attention to the $900^{\circ}-1000^{\circ} \mathrm{C}$ temperature range, where crystallization occurs. The spectrum of the $400^{\circ} \mathrm{C}$ sample shows three main components with maxima at 1, 30, and $55 \mathrm{ppm}$, which are assigned to hexacoordinated, pentacoordinated, and tetracoordinated aluminum sites, respectively. ${ }^{24,29-32}$ As samples are heated progressively to $950^{\circ} \mathrm{C}$, the spectra show a relative increase in the peak intensity due to pentacoordinated aluminum sites. At $1000^{\circ} \mathrm{C}$, the intensity of the pentacoordinated aluminum peak decreases suddenly. At $1300^{\circ}$ and $1400^{\circ} \mathrm{C}$, the spectra are characteristic of a crystalline mullite phase with one hexacoordinated and two tetracoordinated sites.

Gerardin et al. ${ }^{24}$ discussed the importance of pentacoordinated aluminum sites in the amorphous phase in obtaining low-temperature mullitization. Their homogeneously mixed 


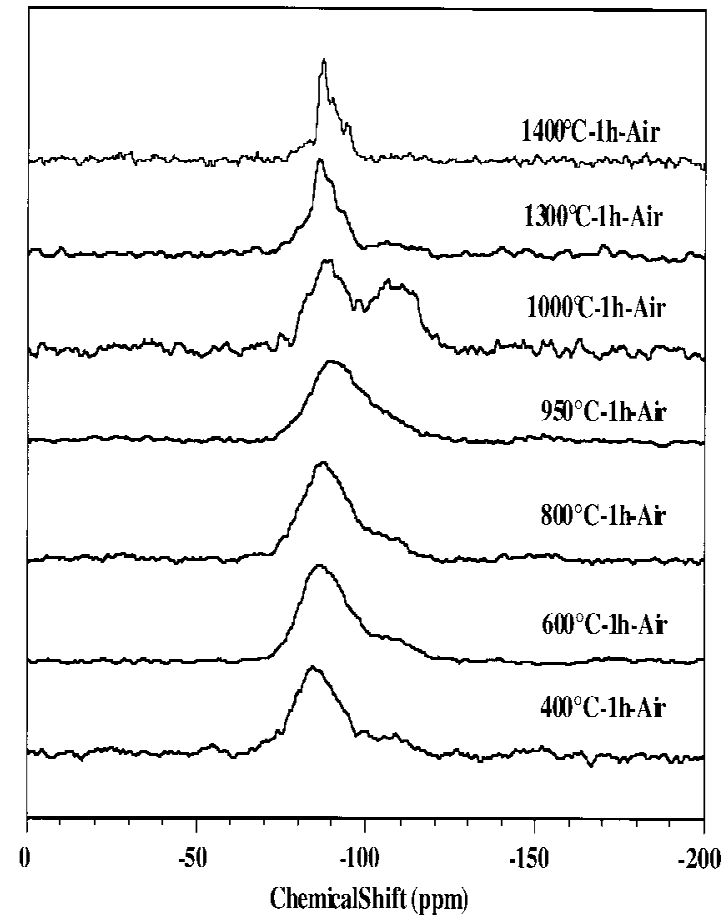

Fig. 4. ${ }^{29} \mathrm{Si}$ MAS NMR spectra of mullite precursor pyrolyzed to selected temperatures.

precursor also contained considerable amounts of pentacoordinated sites in the sample that was pyrolyzed to $900^{\circ} \mathrm{C}$, which disappeared at $1000^{\circ} \mathrm{C}$, as is observed in our samples. However, phase-pure mullite was not obtained at $1000^{\circ} \mathrm{C}$ (by XRD) and a small amount of a spinel phase was obtained. The pentacoordinated sites were absent in a less-homogeneously mixed precursor that showed an exotherm at $1295^{\circ} \mathrm{C}$ and a crystalline pattern for mullite only at $1300^{\circ} \mathrm{C}$. Pentacoordinated sites seem to be critical to the direct mullitization of amorphous mullite composition materials (vide infra).

\section{(5) DRIFT Spectroscopy}

The DRIFT patterns for the mullite precursor that has been pyrolyzed in air to selected temperatures are displayed in Fig. 8. The various vibrational modes that are present in the pyrolyzed materials at selected temperatures are discussed below.

The broad envelope of $v(\mathrm{Si}-\mathrm{O})$ and $v(\mathrm{Al}-\mathrm{O})$ bands at $<1100$ $\mathrm{cm}^{-1}$, which are observed at temperatures $\leqslant 1000^{\circ} \mathrm{C}$, indicate a diverse number of atomic environments, typical of amorphous materials. The peaks grow sharper at temperatures $\geqslant 1200^{\circ} \mathrm{C}$ as the samples become more crystalline. The long-range order (periodicity) that is found in crystalline materials limits the number of vibrational modes that are available to each bonding pair in a particular atomic environment, which results in sharp infrared (IR) bands.

The spectra at $400^{\circ}, 600^{\circ}$, and $800^{\circ} \mathrm{C}$ show $\nu(\mathrm{O}-\mathrm{H})$ bands at $3200 \mathrm{~cm}^{-1}$, with an overtone at $1600 \mathrm{~cm}^{-1}$. These bands probably do not result from adsorbed $\mathrm{H}_{2} \mathrm{O}$ species from the atmosphere; otherwise, they also would appear in the highertemperature pyrolyzed samples. Their presence indicates the formation of $\mathrm{Si}(\mathrm{O})_{x}(\mathrm{OH})_{y}$ and $\mathrm{Al}(\mathrm{O})_{m}(\mathrm{OH})_{n}$ species during pyrolysis. These bands weaken at $800^{\circ} \mathrm{C}$ and disappear above this temperature. This observation supports the idea that oxidative removal of char generates $\mathrm{H}_{2} \mathrm{O}$, which, in turn, generates new $\mathrm{MOH}$ groups, as suggested above. Further support for in situ generation of $\mathrm{MOH}$ groups comes from a comparison of the pyrolysis behavior of an OOPS $\mathrm{K}_{2} \mathrm{O} \cdot \mathrm{Al}_{2} \mathrm{O}_{3} \cdot 2 \mathrm{SiO}_{2}$ precursor with a hydrolytically produced $\mathrm{K}_{2} \mathrm{O} \cdot \mathrm{Al}_{2} \mathrm{O}_{3} \cdot 2 \mathrm{SiO}_{2}$ gel. Pyrolysis of gel-derived samples does not produce new M-OH groups. ${ }^{20}$

As noted above, oxidative crosslinking leads to char, which is stable to $\sim 600^{\circ} \mathrm{C}$. Thus, at temperatures $<800^{\circ} \mathrm{C}$, oxidation of retained $\mathrm{C}-\mathrm{H}$ bonds generates $\mathrm{H}_{2} \mathrm{O}$, which, in turn, generates new $\mathrm{M}-\mathrm{OH}$ groups. Continual generation of $\mathrm{Si}(\mathrm{O})_{x}(\mathrm{OH})_{y}$ and $\mathrm{Al}(\mathrm{O})_{m}(\mathrm{OH})_{n}$ species, as evidenced by the presence of $v(-\mathrm{OH})$ bands, means that $\mathrm{Si}-\mathrm{O}-\mathrm{Al}$ network formation is not complete. Only at higher temperatures $\left(\sim 800^{\circ} \mathrm{C}\right)$, where all the char has oxidized, will the remaining $\mathrm{Si}(\mathrm{O})_{x}(\mathrm{OH})_{y}$ and $\mathrm{Al}(\mathrm{O})_{m}(\mathrm{OH})_{n}$ species combine (by condensation reactions) to form a complete and extended $\mathrm{Si}-\mathrm{O}-\mathrm{Al}$ network, as evidenced by the disappearance of $v(-\mathrm{OH})$ bands.

The literature reports standard mullite IR spectra as consisting of the following: tetrahedral $\left(\mathrm{SiO}_{4}\right) \nu(\mathrm{Si}-\mathrm{O})$ vibrations at 1130 and $1170 \mathrm{~cm}^{-1}$, tetrahedral $\left(\mathrm{AlO}_{4}\right) \nu(\mathrm{Al}-\mathrm{O})$ vibrations at

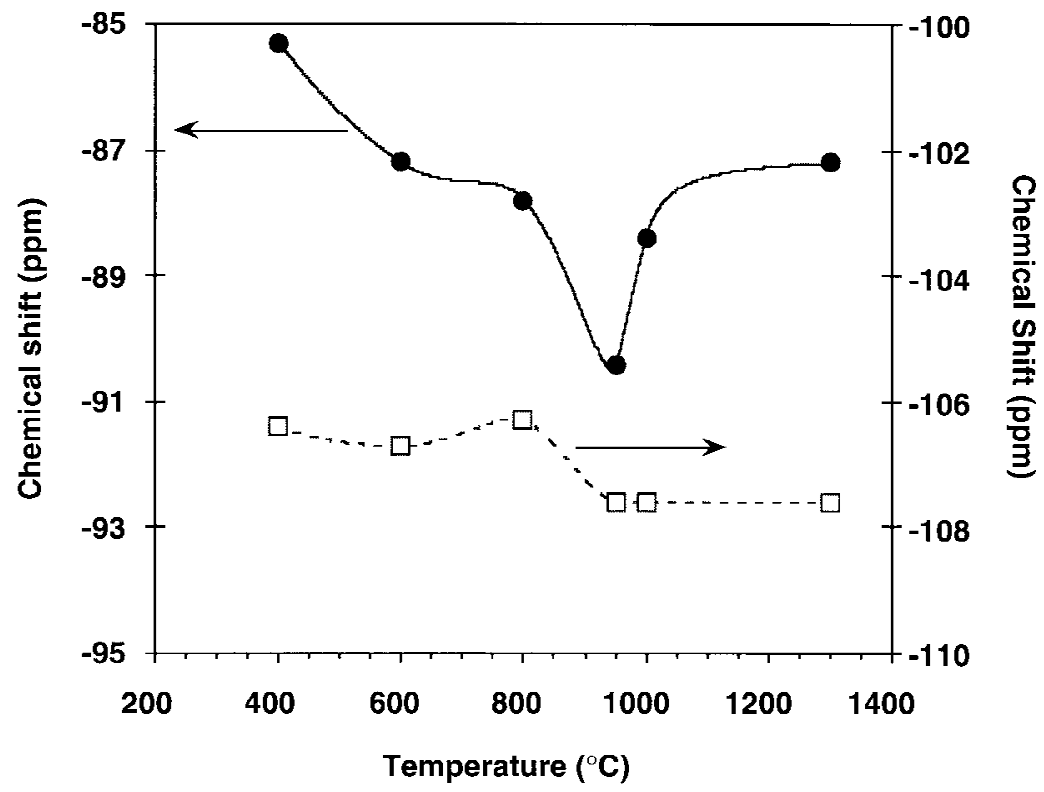

Fig. 5. Plot of chemical shifts versus selected temperatures from ${ }^{29} \mathrm{Si}$ MAS NMR spectra of pyrolyzed mullite precursor $((\mathbf{O}) \mathrm{Si}-\mathrm{O}-\mathrm{Al}$ peak and ( $\square$ ) $\mathrm{Si}-\mathrm{O}-\mathrm{Si}$ peak). 


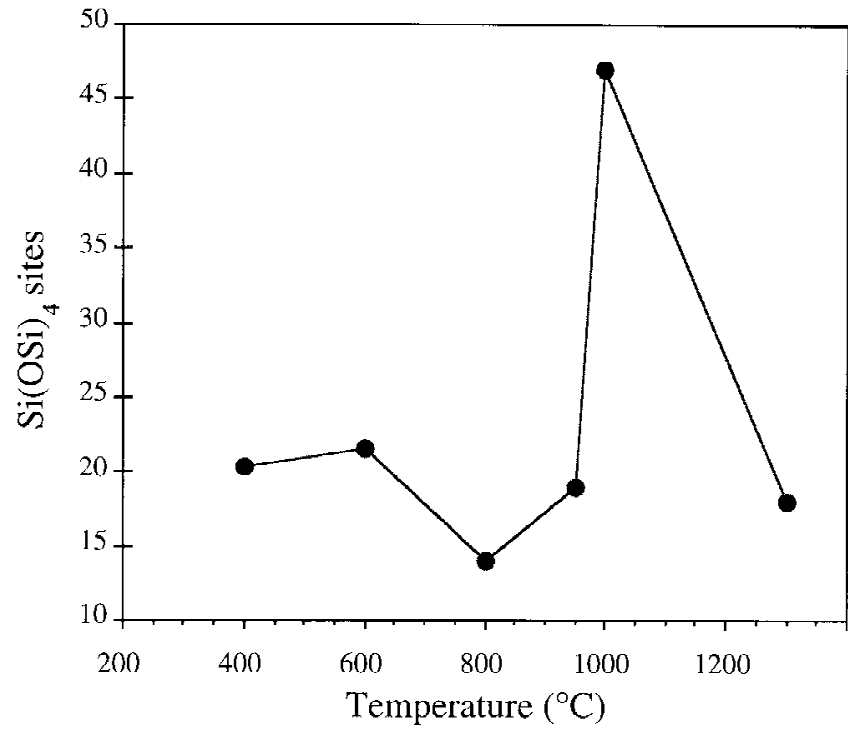

Fig. 6. Plot of percentage of $\mathrm{Si}(\mathrm{OSi})_{4}$ sites versus selected temperatures from ${ }^{29} \mathrm{Si}$ MAS NMR spectra of pyrolyzed mullite precursor.

740 and $830 \mathrm{~cm}^{-1}$, and octahedral $\left(\mathrm{AlO}_{6}\right) v(\mathrm{Al}-\mathrm{O})$ vibrations in the range of 530-680 $\mathrm{cm}^{-1} \cdot 33-35$ The two bands for $\mathrm{AlO}_{4}$ and $\mathrm{AlO}_{6}$ probably each result from $\mathrm{Si}-\mathrm{O}-\mathrm{Al}$ and $\mathrm{Al}-\mathrm{O}-\mathrm{Al}$ bonds. In the following, each type of vibration and the changes that occur at different pyrolysis temperatures are discussed.

(A) $\mathrm{SiO}_{4} v(\mathrm{Si}-\mathrm{O})$ Vibrations: At temperatures in the range of $400^{\circ}-1200^{\circ} \mathrm{C}$, the spectra show a band at $\sim 1100 \mathrm{~cm}^{-1}$, which is attributed to tetrahedral $\nu(\mathrm{Si}-\mathrm{O})$ vibrations, as found in $\mathrm{SiO}_{2}$ (vide infra). At $1300^{\circ} \mathrm{C}$, this band shifts and splits to 1170 and $1120 \mathrm{~cm}^{-1}$. These values correspond to the literature values for tetrahedral $v(\mathrm{Si}-\mathrm{O})$ vibrations in mullite. ${ }^{33-35}$

(B) $\mathrm{AlO}_{4} v(\mathrm{Al}-\mathrm{O})$ Vibrations: No well-defined bands due to $\mathrm{AlO}_{4} v(\mathrm{Al}-\mathrm{O})$ vibrations are observed at $400^{\circ}, 600^{\circ}$, or $800^{\circ} \mathrm{C}$. At these temperatures, a broad envelope, centered at $700 \mathrm{~cm}^{-1}$, most likely results from mixed bands due to $\mathrm{AlO}_{4}$ and $\mathrm{AlO}_{6} v(\mathrm{Al}-\mathrm{O})$ vibrations. At $900^{\circ} \mathrm{C}$, a weak band at 720

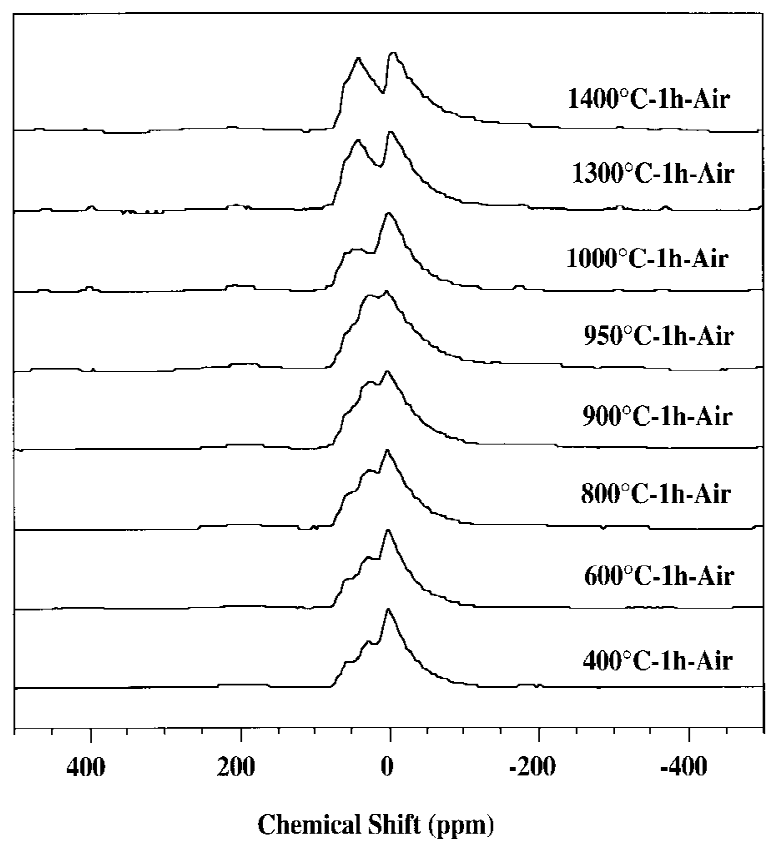

Fig. 7. ${ }^{27} \mathrm{Al}$ MAS NMR spectra of mullite precursor pyrolyzed to selected temperatures.

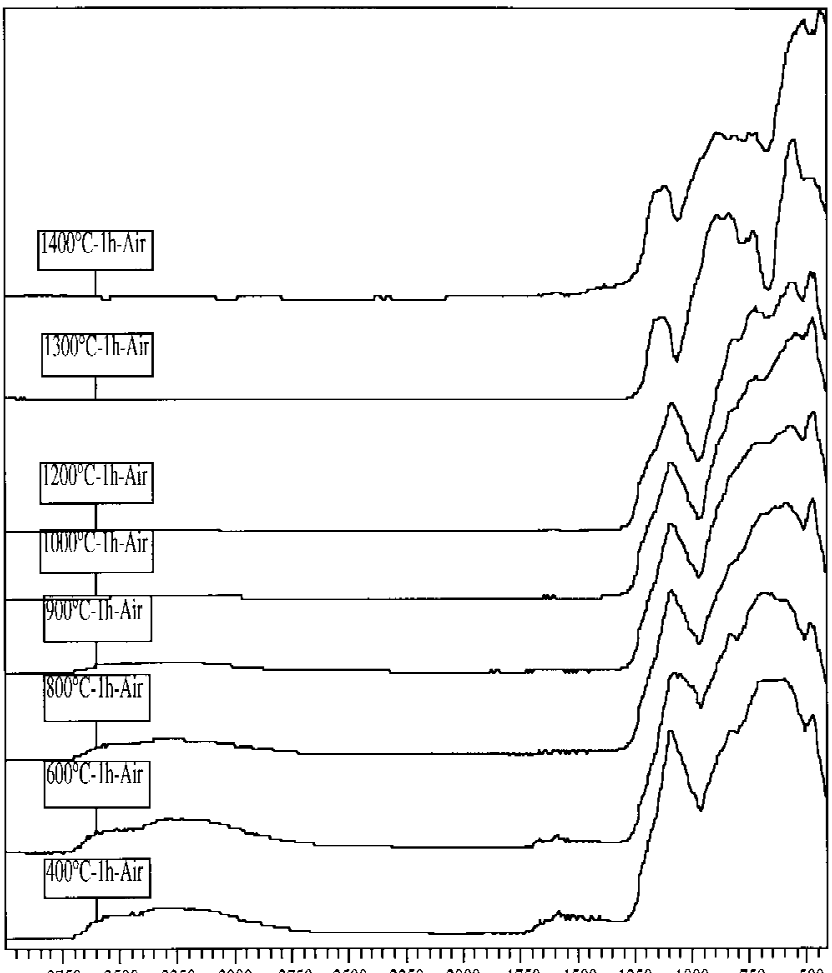

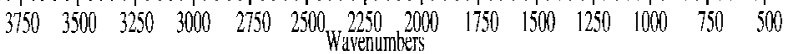

Fig. 8. DRIFT spectra of mullite precursor pyrolyzed to selected temperatures.

$\mathrm{cm}^{-1}$ can be attributed to $\mathrm{AlO}_{4} v(\mathrm{Al}-\mathrm{O})$ vibrations. At $1000^{\circ} \mathrm{C}$, the band shifts to $740 \mathrm{~cm}^{-1}$ (literature value), because a moreordered structure forms (coincides with the crystallization that is indicated by XRD), and continues to sharpen at $1200^{\circ}$ and $1300^{\circ} \mathrm{C}$. Another band at $830 \mathrm{~cm}^{-1}$ (absent at lower temperatures), also typical of $\mathrm{AlO}_{4} v(\mathrm{Al}-\mathrm{O})$ vibrations that are associated with mullite, is first observed at $1200^{\circ} \mathrm{C}$ and sharpens at $1300^{\circ} \mathrm{C}$

(C) $\mathrm{AlO}_{6} \mathrm{v}(\mathrm{Al}-\mathrm{O})$ Vibrations: In the temperature range of $400^{\circ}-800^{\circ} \mathrm{C}$, no bands due to $\mathrm{AlO}_{6} v(\mathrm{Al}-\mathrm{O})$ vibrations can be observed, although, as explained above, they are probably part of the broad envelope centered at $700 \mathrm{~cm}^{-1}$. At $900^{\circ}$ and $1000^{\circ} \mathrm{C}$, a broad (ill-defined) band at $580 \mathrm{~cm}^{-1}$ is attributed to $\mathrm{AlO}_{6} v(\mathrm{Al}-\mathrm{O})$ vibrations. At $1200^{\circ}$ and $1300^{\circ} \mathrm{C}$, the band sharpens with crystallization.

\section{(6) Precursor Evolution on Pyrolysis}

The above-mentioned results, considered in toto, can be used to provide a detailed picture of the processes that occur during pyrolytic conversion of the OOPS precursor to crystalline, orthorhombic mullite. In particular, we are interested in how the amorphous $\mathrm{Si}-\mathrm{O}-\mathrm{Al}$ network that is formed at $\sim 400^{\circ} \mathrm{C}$ transforms. All the analytical studies indicate that the most-dramatic changes occur as the heat-treatment temperature reaches $\sim 1000^{\circ} \mathrm{C}$. Before $1000^{\circ} \mathrm{C}$, only DRIFT spectroscopy and NMR provide any indications of change.

The primary changes in the DRIFT spectra (Fig. 8) are the slow disappearance of $v(\mathrm{O}-\mathrm{H})$ vibrations, as $\mathrm{M}-\mathrm{OH}$ groups slowly condense, eliminate $\mathrm{H}_{2} \mathrm{O}$, and complete formation of the three-dimensional $\mathrm{Si}-\mathrm{O}-\mathrm{Al}$ network at $\sim 900^{\circ} \mathrm{C}$. Much of this likely occurs on the surface of the material ${ }^{20}$ as the surface area decreases from $300 \mathrm{~m}^{2} / \mathrm{g}$ to $<150 \mathrm{~m}^{2} / \mathrm{g}$ (vide infra). The ${ }^{29} \mathrm{Si}$ NMR provides a more-detailed picture of network formation and behavior than DRIFT spectroscopy.

The ${ }^{29} \mathrm{Si}$ MAS NMR, at lower temperatures, indicates that the $400^{\circ} \mathrm{C}$ material contains $\sim 20 \% \mathrm{Si}(\mathrm{OSi})_{4}$ sites; however, the primary sites are due to the $\mathrm{Si}-\mathrm{O}-\mathrm{Al}$ network $(80 \%$, Figs. 5 and 6). If we start with a homogeneously mixed precursor with 


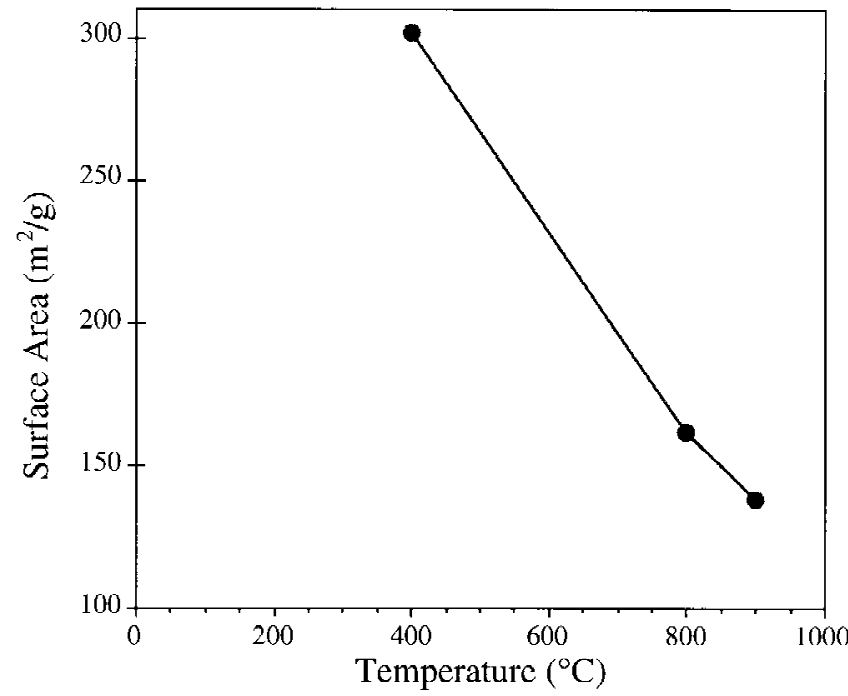

Fig. 9. Plot of surface area as a function of temperature for pyrolyzed mullite precursor.

the stoichiometric composition of mullite (3:1 $\mathrm{Al}: \mathrm{Si}$ ratio), then, on pyrolysis, we should obtain a homogeneous, but amorphous, phase. ${ }^{29} \mathrm{Si} \mathrm{NMR}$ of this material will give an envelope of environments for silicon wherein the most common has an average of three aluminum atoms that are bound, through oxygen, to one silicon atom. However, tetrahedral silicon has a fourth position that can be occupied by another $\mathrm{O}-\mathrm{Si}$, another $\mathrm{O}-\mathrm{Al}$, or $\mathrm{OH}$. If we ignore $\mathrm{OH}$ for the moment, a statistical argument would have the fourth position being occupied most frequently by aluminum; this will result in an envelope of ${ }^{29} \mathrm{Si}$ environments with a maximum at a $3: 1 \mathrm{Al}: \mathrm{Si}$ ratio and skewed toward a small component that consists of $\mathrm{Si}(\mathrm{OSi})_{4}$ sites, as shown in Fig. 4. The smoothest envelopes occur at $800^{\circ}-$ $900^{\circ} \mathrm{C}$. Why is a smooth envelope that reflects a statistical average of environments not obtained at lower temperatures?

As shown by DRIFT spectroscopy, some $\mathrm{OH}$ groups are present at moderate temperatures. Thus, species such as $\mathrm{Si}(\mathrm{O})_{x}(\mathrm{OH})_{y}$ and $\mathrm{Al}(\mathrm{O})_{m}(\mathrm{OH})_{n}$ are present. On heating, these groups react (by condensation) to form $\mathrm{Si}-\mathrm{O}-\mathrm{Si}, \mathrm{Al}-\mathrm{O}-\mathrm{Si}$, or $\mathrm{Al}-\mathrm{O}-\mathrm{Al}$ bonds. It is quite possible that $\mathrm{Si}-\mathrm{O}-\mathrm{Si}$ and $\mathrm{Al}-\mathrm{O}-\mathrm{Al}$ bonds form in preference to $\mathrm{Al}-\mathrm{O}-\mathrm{Si}$ bonds; this would account, at least in part, for the lower-temperature segregation. On heating to higher temperatures, diffusion rates finally become sufficiently high to give (by $800^{\circ} \mathrm{C}$ ) a truly statistical distribution. Based on ${ }^{29} \mathrm{Si} \mathrm{NMR}$ and statistical arguments, the material seems to be truly homogeneous.

In the ${ }^{27} \mathrm{Al} \mathrm{NMR}$ studies, the only definitive change that occurs as the samples are heated to $950^{\circ} \mathrm{C}$ is the growth of the pentacoordinated-aluminum peak at $30 \mathrm{ppm}$. This change occurs coincident with the homogenization of the ${ }^{29} \mathrm{Si}$ NMR signals. Thus, a high percentage of pentacoordinated-aluminum sites may be an indicator for the formation of a homogeneous, amorphous material of mullite composition. ${ }^{24,27,29-32}$ At this point, additional heating causes tremendous changes.

As the samples are heated from $950^{\circ}$ to $1000^{\circ} \mathrm{C}$, (i) an exotherm is observed in the DTA, (ii) a mullite powder XRD pattern appears, (iii) ${ }^{29} \mathrm{Si}$ NMR shows extensive segregation, and (iv) ${ }^{27} \mathrm{Al}$ NMR shows the complete disappearance of the pentacoordinated aluminum species. For example, when going from $950^{\circ} \mathrm{C}$ to $1000^{\circ} \mathrm{C}$, the number of silicon atoms in $\mathrm{Si}(\mathrm{OSi})_{4}$ environments increases from $20 \%$ to $47 \%$. In keeping with the segregation that is shown by ${ }^{29} \mathrm{Si} \mathrm{NMR}$, the $1000^{\circ} \mathrm{C}$ sample provides a DRIFT spectrum with a broad $v(\mathrm{Si}-\mathrm{O})$ band at 1100 $\mathrm{cm}^{-1}$, which is typical of $\mathrm{SiO}_{4}$ sites in silicates, rather than bands at 1130 and $1170 \mathrm{~cm}^{-1}$, which are typical of aluminosilicates (e.g., the $1300^{\circ} \mathrm{C}$ sample). In addition, the envelope of $v(\mathrm{Al}-\mathrm{O})$ vibrations (centered at $700 \mathrm{~cm}^{-1}$ ) suggests a wide

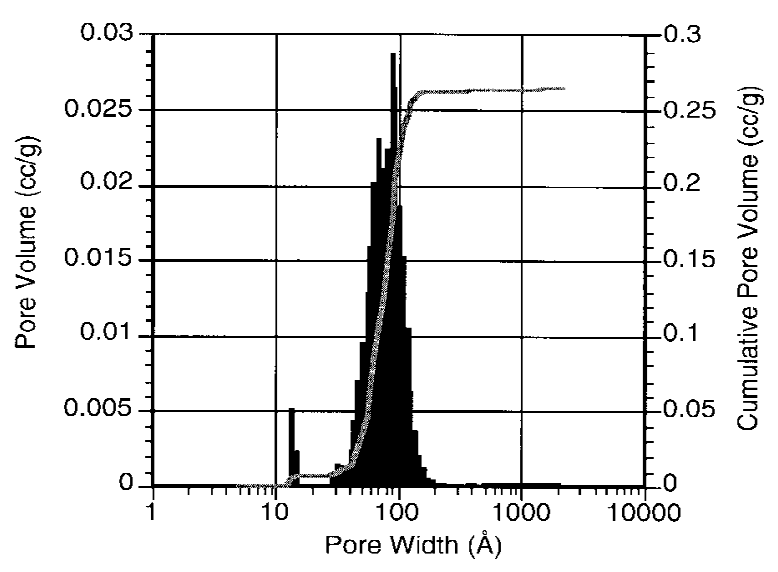

Fig. 10. Plot of pore-size distribution for mullite precursor pyrolyzed to $900^{\circ} \mathrm{C}$ for $1 \mathrm{~h}$ in air.

variety of vibrational modes that are typical of amorphous rather than crystalline materials (see the $1300^{\circ} \mathrm{C}$ sample). Hence, the $1000^{\circ} \mathrm{C}$ sample seems to contain significant amounts of amorphous material.

The processes that occur at $1000^{\circ} \mathrm{C}$ remain the subject of much controversy. Some researchers ${ }^{9,10,28}$ have suggested that the exotherm at $990^{\circ} \mathrm{C}$ results from the reaction of an $\mathrm{Al}_{2} \mathrm{O}_{3}$ rich spinel phase with the segregated amorphous $\mathrm{SiO}_{2}$ to form mullite. Thomson et al., ${ }^{24}$ Jaymes et al., ${ }^{27}$ and Huling and Messing ${ }^{26}$ suggested that it results from the formation of $\mathrm{Al}_{2} \mathrm{O}_{3}$-rich tetragonal mullite coincident with the demixing of $\mathrm{SiO}_{2}$. Tetragonal mullite seems to have an $\mathrm{Al}$ :Si composition of $\sim 4: 1$, although it could be more aluminum-rich. ${ }^{25,26}$

The complete disappearance of pentacoordinated aluminum coincides with the exotherm at $980^{\circ} \mathrm{C}$. Thus, another explanation for this exotherm is that it results from the transformation of pentacoordinated aluminum atoms to more-stable tetrahedral and octahedral coordination. ${ }^{24-27}$ This argument is not inconsistent with a crystallization event; it simply explains what occurs at the atomic level.

XRD studies correlate the exotherm at $990^{\circ} \mathrm{C}$ with the crystallization of mullite. However, NMR and DRIFT spectroscopy indicate that whatever crystallization event does occur, sudden demixing of $\mathrm{SiO}_{2}(\sim 47 \%$ vs. $20 \%)$ occurs coincidentally and considerable amounts of amorphous material remain. If tetragonal mullite crystallizes with an Al:Si composition closer to 4:1 than $3: 1$, then $\mathrm{SiO}_{2}$ demixing should be expected. For a $4: 1$ ratio, one can calculate that $\sim 25 \mathrm{~mol} \%$ excess $\mathrm{SiO}_{2}$ should be present as a second phase. The fact that we observe $47 \mathrm{~mol} \%$ suggests that tetragonal mullite, if it forms, is more aluminumrich. If the ratio were $5: 1$, then demixing should produce $\sim 40$ $\mathrm{mol} \%$ free $\mathrm{SiO}_{2}$, which is closer to $47 \mathrm{~mol} \%$. Thus, if tetragonal mullite forms initially, its $\mathrm{Al}: \mathrm{Si}$ composition is closer to 5:1. ${ }^{25,26}$ Thus, the crystallization of $\mathrm{Al}_{2} \mathrm{O}_{3}$-rich tetragonal mullite can account for the exotherm at $980^{\circ} \mathrm{C}$, the mullite powder XRD pattern at $1000^{\circ} \mathrm{C}$, and the demixing of $\mathrm{SiO}_{2}$. Its formation also explains the DRIFT spectra that are obtained at temperatures of $\geqslant 1000^{\circ} \mathrm{C}$.

The formation of considerable amounts of free $\mathrm{SiO}_{2}$ explains the $1100 \mathrm{~cm}^{-1} v(\mathrm{Si}-\mathrm{O})$ band that is typical of pure $\mathrm{SiO}_{2}$ in the $1000^{\circ} \mathrm{C}$ spectrum. Because the material seems to be homogeneous at $950^{\circ} \mathrm{C}$, demixing at $1000^{\circ} \mathrm{C}$ should occur homogeneously, e.g., as in spinodal decomposition. Therefore, tetragonal mullite grains should form in an amorphous $\mathrm{SiO}_{2}$ matrix. The matrix/mullite interfacial interactions will influence the $\mathrm{Al}-\mathrm{O}$ bonding environments and could cause the broad envelope of $v(\mathrm{Al}-\mathrm{O})$ vibrations that is observed at $1000^{\circ} \mathrm{C}$.

As the samples are heated to $1300^{\circ}$ and then to $1400^{\circ} \mathrm{C}$, the ${ }^{29} \mathrm{Si} \mathrm{NMR}$ indicates that the demixed $\mathrm{SiO}_{2}$ readsorbs $(18 \%$ at $1300^{\circ} \mathrm{C}$ ) as the literature peaks for phase-pure orthorhombic mullite appear. ${ }^{24-28}$ In the DRIFT spectra, the $1100 \mathrm{~cm}^{-1}$ 
$v(\mathrm{Si}-\mathrm{O})$ band splits into the 1130 and $1170 \mathrm{~cm}^{-1}$ bands, as expected for mullite, and another tetrahedral $\nu(\mathrm{Si}-\mathrm{O})$ band that is typical of mullite appears at $900 \mathrm{~cm}^{-1} \cdot{ }^{33-35}$ Similarly, the powder XRD pattern peaks sharpen and increase in intensity.

Based on the above-mentioned analysis and the work of Gerardin et al., ${ }^{24}$ Jaymes et al., ${ }^{27}$ and Huling and Messing, ${ }^{26}$ we conclude that the OOPS precursor, when heated in air to temperatures of $400^{\circ}-600^{\circ} \mathrm{C}$, first decomposes to a homogeneous, amorphous material with a mullite composition. When heated further to $1000^{\circ} \mathrm{C}$, this material crystallizes to an $\mathrm{Al}_{2} \mathrm{O}_{3^{-}}$rich tetragonal mullite with coincident demixing of considerable amounts of amorphous $\mathrm{SiO}_{2}$. Finally, at temperatures of $\geqslant 1300^{\circ} \mathrm{C}$, the demixed $\mathrm{SiO}_{2}$ readsorbs as stoichiometric orthorhombic mullite finally crystallizes.

\section{(7) Specific Surface Area and Porosimetry}

Figure 9 shows a plot of the surface area as a function of precursor pyrolysis temperature. This characterization technique gives Brunauer-Emmett-Teller method (BET) surface area, pore size, and pore-size distribution. As the pyrolysis temperature increases, densification occurs via diffusion, which results in the reduction of surface area. ${ }^{20}$ The exceptionally high surface area for the $400^{\circ} \mathrm{C}$ sample is probably due to some porous char ( $20 \%$ from TGA) that remains in the material, as shown in related efforts. ${ }^{36}$ Figure 10 gives the pore-size distribution for the mullite sample pyrolyzed to $900^{\circ} \mathrm{C}$ for $1 \mathrm{~h}$ in air. The mean pore size is $\sim 80 \AA \mathrm{A}(8 \mathrm{~nm})$.

SEM micrographs (not shown) of as-fired surfaces were taken of mullite precursor that was pyrolyzed to $1000^{\circ}$ and $1400^{\circ} \mathrm{C}$. At $1000^{\circ} \mathrm{C}$, no visible pores were observed and only hints of microstructural development were observed. The SEM micrographs at $1400^{\circ} \mathrm{C}$ revealed some texture that was associated with the appearance of small $(\sim 0.2-0.3 \mu \mathrm{m})$ grains and some pores that probably resulted from grain growth without densification. These results are consistent with all the other analytical data, which indicates that fully crystalline mullite forms only at temperatures of $\geqslant 1300^{\circ} \mathrm{C}$, not at $1000^{\circ} \mathrm{C}$.

\section{Conclusions}

The mullite precursor used in the studies reported here was synthesized directly from $\mathrm{SiO}_{2}, \mathrm{Al}(\mathrm{OH})_{3}$, and triethanolamine in ethylene glycol by a direct, low-temperature route. Based on the above-mentioned analyses and the work of Gerardin et al. ${ }^{24}$ Jaymes et al., ${ }^{27}$ and Huling and Messing, ${ }^{26}$ we conclude that the OOPS precursor, when heated in air to temperatures of $400^{\circ}-600^{\circ} \mathrm{C}$, first decomposes to a homogeneous, amorphous material with a mullite composition. When heated further to $1000^{\circ} \mathrm{C}$, this material crystallizes to an $\mathrm{Al}_{2} \mathrm{O}_{3}$-rich tetragonal mullite with coincident demixing of considerable amounts of amorphous $\mathrm{SiO}_{2}$. Finally, at temperatures of $\geqslant 1300^{\circ} \mathrm{C}$, the demixed $\mathrm{SiO}_{2}$ readsorbs as stoichiometric orthorhombic mullite finally crystallizes.

Thus, the OOPS-derived precursor behaves as a "singlephase" (as defined in the literature), atomically mixed precursor. The results that have been presented indicate that this precursor behaves identically to the mullite precursors that were synthesized by various methods (sol-gel, slowly hydrolyzed gels, etc.) that have been reported in the literature. , $^{1,24-27}$ Perhaps most importantly, this precursor can be made in large quantities in a few hours; in contrast, sol-gel processing of atomically mixed mullite materials can require weeks. ${ }^{25-27}$

Acknowledgment: The authors would like to thank K. W. Chew for characterizing the tetragonal-to-orthorhombic transformation process.

\section{References}

${ }^{1}$ M. D. Sacks, H.-W. Lee, and J. A. Pask, "A Review of Powder Preparation Methods and Densification Procedures for Fabricating High-Density Mullite"; pp. 167-207 in Ceramic Transactions, Vol. 6, Mullite and Mullite Matrix Composites. Edited by S. Sōmiya, R. F. Davis, and J. A. Pask. American Ceramic Society, Westerville, OH, 1990 and references therein

${ }^{2}$ V. Ramakrishnan, E. Goo, J. M. Roldan, and E. A. Giess, "Microstructure of Mullite Ceramics Used for Substrate and Packaging Applications," J. Mater. Sci., 27, 6127-30 (1992).

${ }^{3}$ P. C. Dokko, J. A. Pask, and K. S. Mazdiyasni, "High-Temperature Mechanical Properties of Mullite Under Compression," J. Am. Ceram. Soc., 60 [3-4] 150-55 (1977)

${ }^{4}$ D.-Y. Jeng and M. N. Rahaman, "Sintering and Crystallization of Mullite Powder Prepared by Sol-Gel Processing," J. Mater. Sci. 28, 4904-909 (1993).

${ }^{5}$ A. G. Williams and L. V. Interrante, "Design of Metal-Organic Precursors to Aluminosilicates," Mater. Res. Soc. Symp. Proc., 32, 151-56 (1984).

${ }^{6} \mathrm{~S}$. Prochazka and F. J. Klug, "Infrared Transparent Mullite Ceramics," J. Am. Ceram. Soc., 66 [12] 874-80 (1983).

${ }^{7}$ M. Ohashi, H. Tabata, O. Abe, S. Kanzaki, S. Mitachi, and T. Kumazawa, "Preparation of Translucent Ceramics"' J. Mater. Sci. Lett., 6, 528-30 (1987).

${ }^{8}$ (a) W.-C. Wei and J. W. Halloran, "Phase Transformations of Diphasic Aluminosilicate Gels," J. Am. Ceram. Soc., 71 [3] 166-72 (1988). (b) W.-C. Wei and J. W. Halloran, "Transformation Kinetics of Diphasic Aluminosilicate Gels," J. Am. Ceram. Soc., 71 [7] 581-87 (1988).

${ }^{9}$ I. A. Aksay, D. M. Dobbs, and M. Sarikaya, "Mullite for Structural, Electronic, and Optical Applications," J. Am. Ceram. Soc., 74 [10] 2343-58 (1991) and references therein.

${ }^{10}$ W. G. Fahrenholtz and D. M. Smith, "Effect of Precursor Particle Size on the Densification and Crystallization Behavior of Mullite," J. Am. Ceram. Soc., 76 [2] 433-37 (1993) and references therein.

${ }^{11}$ R. R. Tummala, "Ceramic and Glass-Ceramic Packaging in the 1990s," $J$. Am. Ceram. Soc., 74 [5] 895-908 (1991).

${ }^{12} \mathrm{H}$. Schneider and E. Eberhard, "Thermal Expansion of Mullite," J. Am. Ceram. Soc., 73 [7] 2073-76 (1990).

${ }^{13}$ A. J. Skoog and R. E. Moore, "Refractory of the Past for the Future: Mullite and Its Use as a Bonding Phase," Am. Ceram. Soc. Bull., 67 [7] 118085 (1988).

${ }^{14}$ K. A. Moore, J. Cesarano III, D. M. Smith, and T. T. Kodas, "Synthesis of Submicrometer Mullite Powder via High-Temperature Aerosol Decomposition," J. Am. Ceram. Soc., 75 [1] 213-15 (1992).

${ }^{15} \mathrm{~K}$. S. Mazdiyasni and L. M. Brown, "Synthesis and Mechanical Properties of Stoichiometric Aluminum Silicate (Mullite)," J. Am. Ceram. Soc., 55 [11] 548-52 (1972).

${ }^{16}$ T.-I. Mah and K. S. Mazdiyasni, "Mechanical Properties of Mullite," J. Am. Ceram. Soc., 66 [10] 699-703 (1983).

${ }^{17}$ I. A. Aksay and J. A. Pask, "Stable and Metastable Equilibria in the System $\mathrm{SiO}_{2}-\mathrm{Al}_{2} \mathrm{O}_{3}$," J. Am. Ceram. Soc., 58 [11-12] 507-12 (1975).

${ }^{18}$ S. Sōmiya and Y. Hirata, "Mullite Powder Technology and Applications in Japan," Am. Ceram. Soc. Bull., 70 [10] 1624-32 (1991).

${ }^{19}$ (a) R. M. Laine, D. R. Treadwell, B. L. Mueller, C. R. Bickmore, K. F. Waldner, and T. Hinklin, "Processable Aluminosilicate Alkoxide Precursors from Metal Oxides and Hydroxides. The Oxide One Pot Synthesis (OOPS) Process," J. Chem. Mater., 6, 1441-43 (1996). (b) K. Waldner, R. M. Laine, C. Bickmore, S. Dumrongvaraporn, and S. Tayaniphan, "Synthesis, Processing and Pyrolytic Transformation of a Spinel Polymer Precursor Made from $\mathrm{MgO}$ and $\mathrm{Al}(\mathrm{OH})_{3}$, , Chem. Mater., 8, 2850-57 (1996).

${ }^{20}$ R. Baranwal and R. M. Laine, "A Preceramic Polymer Route to Amorphous and Crystalline Potassium Aluminosilicate Powders and Their Electrorheological Properties," J. Am. Ceram. Soc., 80 [6] 1436-46 (1997).

${ }^{21}$ (a) P. Kansal and R. M. Laine, "Mullite Coatings on Carbon Fibers: Precursor Synthesis, Coating Processing, Characterization and Oxidation Resistance," manuscript in preparation. (b) P. Kansal, "Novel Chemical Routes to Ceramics from Precursors"; Ph.D. Dissertation. University of Michigan, Ann Arbor, MI, Jan. 1996.

${ }^{22}$ R. M. Laine, "Chemicals, Polymers and Ceramics from the Beach. II"; pp. 69-78 in Applications of Organometallic Chemistry in the Preparation and Processing of Advanced Materials, NATO ASI Series E: Applied Sciences, Vol. 297. Edited by J. F. Harrod and R. M. Laine. Kluwer, Dordrecht, The Netherlands, 1995.

${ }^{23}$ T. Heinrich, W. Tappert, W. Lenhard, and J. Fricke, "Synthesis and Properties of Mullite and Cordierite Aerogels," J. Sol-Gel Sci. Technol., 2, 921-24 (1994).

${ }^{24}$ C. Gerardin, S. Sundaresan, J. Benziger, and A. Navrotsky, "Structural Investigation and Energetics of Mullite Formation from Sol-Gel Precursors,' Chem. Mater., 6, 160-70 (1994).

${ }^{25}$ (a) D. X. Li and W. J. Thomson, "Tetragonal to Orthorhombic Transformation during Mullite Formation," J. Mater. Res., 6 [4] 819-24 (1991). (b) D. X. Li and W. J. Thomson, "Effects of Hydrolysis on the Kinetics of HighTemperature Transformations in Aluminosilicate Gels," J. Am. Ceram. Soc., 74 [3] 574-78 (1991). (c) Y. Wong and W. J. Thomson, "Mullite Formation from Nonstoichiometric Slow Hydrolyzed Single Phase Gels," J. Mater. Res., 10 [4] 912-17 (1995)

${ }^{26}$ (a) J. C. Huling and G. Messing, "Chemistry-Crystallization Relations in Molecular Mullite Gels," J. Non-Cryst. Solids, 147, 213-21 (1992). (b) J. C. Huling and G. L. Messing, "Hybrid Gels for Homoepitactic Nucleation of Mullite," J. Am. Ceram. Soc., 72 [9] 1725-29 (1989).

${ }^{27}$ I. Jaymes, A. Douy, and D. Massiot, "Synthesis of a Mullite Precursor from Aluminum Nitrate and Tetraethoxysilane via Homogeneous Precipitation: An ${ }^{27} \mathrm{Al}$ and ${ }^{29} \mathrm{Si}$ Liquid- and Solid-State NMR Spectroscopic Study," J. Am. Ceram. Soc., 78 [10] 2648-54 (1995).

${ }^{28} \mathrm{~A}$. K. Chakravorty, "Intermediate Si-Al Spinel Phase Formation in Phase Transformation of Diphasic Mullite Gel,"' J. Mater. Sci., 28, 3839-44 (1993).

${ }^{29}$ G. Engelhardt and D. Michel, High Resolution Solid-State NMR of Silicates and Zeolites; pp. 143-57. Wiley, New York, 1987.

${ }^{30} \mathrm{~T}$. Ban and K. Okada, "Analysis of Local Cation Arrangement in Mullite 
Using ${ }^{29}$ Si Magic-Angle Spinning Nuclear Magnetic Resonance Spectra," J. Am. Ceram. Soc., 76 [10] 2491-96 (1993).

${ }^{31}$ J. Sanz, I. Sobrados, L. Cavalieri, P. Pena, S. de Aza, and J. S. Moya, "Structural Changes Induced on Mullite Precursors by Thermal Treatment: A

${ }^{27}$ Al MAS NMR Investigation," J. Am. Ceram. Soc., 74 [10] 2398-403 (1991).

${ }^{32}$ S. Komarneni, R. Roy, C. A. Fyfe, and G. J. Kennedy, "Preliminary Characterization of Gel Precursors and Their High-Temperature Products by ${ }^{27} \mathrm{Al}$ Magic-Angle Spinning NMR," J. Am. Ceram. Soc., 68 [9] C-243-C-245 (1985).

${ }^{33}$ H. J. Percival, J. F. Duncan, and P. K. Foster, "Interpretation of the Ka-
olinite-Mullite Reaction Sequence from Infrared Absorption Spectra," J. Am. Ceram. Soc., 57, 57-61 (1974).

${ }^{34}$ P. Tarte, "Infrared Study of Orthosilicates and Orthogermanates: II," Spectrochim. Acta, Part A, 19 [1] 25-47 (1963).

${ }^{35} \mathrm{P}$. Tarte, "Infrared Spectra of Inorganic Aluminates and Characteristic Vibrational Frequencies of $\mathrm{AlO}_{4}$ Tetrahedra and $\mathrm{AlO}_{6}$ Octahedra," Spectrochim. Acta, Part A, 23 [7] 2127-43 (1967).

${ }^{36} \mathrm{C}$. R. Bickmore and R. M. Laine, "Processing Oxynitride Powders via Fluidized Bed Ammonolysis of Large, Porous Silica Particles," J. Am. Ceram. Soc., 79 [11] 2865-77 (1996). 